Original Article

\title{
Evaluation of indigenous plants' extracts for mosquitocidal activity against different stages of Culex quinquefasciatus say (Diptera: Culicidae)
}

\author{
Avaliação de extratos de plantas indígenas quanto à atividade mosquitocida contra \\ diferentes estágios de culex quinquefasciatus say (Diptera: Culicidae)
}

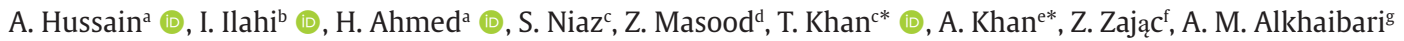 \\ and A. D. Alanazi ${ }^{\text {h }}$ (D) \\ aShaheed Benazir Bhutto University, Department of Zoology, Sheringal, Pakistan \\ bUniversity of Malakand, Department of Zoology, Chakdara, Pakistan \\ 'Abdul Wali Khan University, Department of Zoology, Mardan, Khyber Pakhtunkhwa, Pakistan \\ dSardar Bahadur Khan Woman's University, Department of Zoology, Quetta, Balochistan, Pakistan \\ eBacha Khan University Charsadda, Department of Zoology, Khyber, Pakhtunkhwa, Pakistan \\ fDepartment of Biology and Parasitology, Medical University of Lublin,, Radziwillowska 11, 20-080 Lublin, Poland \\ 'Department of Biology, Faculty of Science, University of Tabuk, Tabuk, Saudi Arabia \\ hDepartment of Biological Sciences, Faculty of Science and Humanities, Shaqra University, P.O. Box 1040, Ad-Dawadimi 11911, Saudi Arabia
}

\begin{abstract}
Being vector of West Nile Virus and falariasis the control of Culex quinquefasciatus is likely to be essential. Synthetic insecticide treatment is looking most effective for vectors mosquito control. However, these products are toxic to the environment and non-target organisms. Consequently, ecofriendly control of vectors mosquito is needed. In this regard botanical insecticide is looking more fruitful. Therefore, the present research aimed to investigate the effectiveness of methanolic extract and various fractions, including, n-hexane, ethyl-acetate, chloroform, and aqueous fraction, obtained from methanolic extract of Ailanthus altissima, Artemisia scoparia, and Justicia adhatoda using separating funnel against larval, pupal, and adult stages of Culex quinquefasciatus. The larvae and pupae of Culex quinquefasciatus were exposed to various concentrations (31.25-1000 ppm) of methanolic extract and its fractions for 24 hours of exposure period. For knock-down bioassay (filter paper impregnation bioassay) different concentration of the methanolic extract and its various fractions (i.e. $0.0625,0.125,0.25,0.5 \mathrm{and} 1 \mathrm{mg}$ / $\mathrm{mL}$ ) were applied for 1 hour exposure period. The results were statistically analysed using standard deviation, probit analysis, and linear regression. The $\mathrm{R}^{2}$ values of larvae, pupae, and adult range from 0.4 to 0.99 . The values of $\mathrm{LC}_{50}$ (concentration causing 50\% mortality) for late $3^{\text {rd }}$ instar larvae after 24 hours exposure period range from 93-1856.7 ppm, while $\mathrm{LC}_{90}$ values range from $424-7635.5 \mathrm{ppm}$. The values of $\mathrm{LC}_{50}$ for pupae range form 1326.7$6818.4 \mathrm{ppm}$ and and values of $\mathrm{LC}_{90}$ range from $3667.3-17427.9 \mathrm{ppm}$, respectively. The $\mathrm{KDT}_{50}$ range from 0.30 to $2.8 \%$ and $\mathrm{KDT}_{90}$ values range from 1.2 to $110.8 \%$, respectively. In conclusion, Justicia adhatoda may be effective for controlling populations of vector mosquito.
\end{abstract}

Keywords: Ailanthus altissima, Artemisia scoparia, Justicia adhatoda knock-down, Mosquitocidal.

\begin{abstract}
Resumo
Por ser o vetor do vírus do Nilo Ocidental e da falaríase, o controle de Culex quinquefasciatus Say é provavelmente essencial. $\mathrm{O}$ tratamento com inseticida sintético parece ser mais eficaz para o controle dos mosquitos vetores. No entanto, esses produtos são tóxicos para o meio ambiente e organismos não visados. Consequentemente, o controle ecológico dos mosquitos vetores é necessário. Nesse sentido, o inseticida botânico parece mais produtivo. Portanto, a presente pesquisa teve como objetivo investigar a eficácia do extrato metanólico e de várias frações, incluindo n-hexano, acetato de etila, clorofórmio e fração aquosa, obtidos do extrato metanólico de Ailanthus altissima (Mill.) Swingle, Artemisia scoparia Waldst. \& Kit. e Justicia adhatoda L. usando funil de separação contra os estágios larval, pupal e adulto de $C$. quinquefasciatus. As larvas e pupas de $C$. quinquefasciatus foram expostas a várias concentrações (31,25-1000 ppm) de extrato metanólico, e suas frações por 24 horas de período de exposição. Para o bioensaio knock-down (bioensaio de impregnação de papel de filtro), diferentes concentrações do extrato metanólico e suas várias frações (ou seja, 0,0625, 0,125, 0,25, 0,5 e $1 \mathrm{mg} / \mathrm{mL}$ ) foram aplicadas por um período de exposição de 1 hora. Os resultados foram analisados estatisticamente usando desvio padrão, análise Probit e regressão linear. Os
\end{abstract}

*e-mail: tawseefkhan055@gmail.com; zoologistawkum@gmail.com

Received: January 29, 2021 - Accepted: July 02, 2021

This is an Open Access article distributed under the terms of the Creative Commons Attribution License, which permits unrestricted use, distribution, and reproduction in any medium, provided the original work is properly cited. 
valores de R2 de larvas, pupas e adultos variaram de 0,4 a 0,99. Os valores de LC50 (concentração que causa 50\% de mortalidade) para larvas de terceiro estádio tardio após 24 horas de período de exposição variaram de 931856,7 ppm, enquanto os valores de LC90 variaram de 424-7635,5ppm. Os valores de LC50 para pupas variaram de 1326,7-6818,4 ppm e os valores de LC90 variaram de 3667,3-17427,9 ppm, respectivamente. O KDT50 variou de 0,30 a 2,8\% e os valores de KDT90 variaram de 1,2 a 110,8\%, respectivamente. Por fim, a espécie J. adhatoda pôde ser eficaz para controlar populações de mosquitos vetores.

Palavras-chave: Ailanthus altissima, Artemisia scoparia, Justicia adhatoda knock-down, Mosquitocida.

\section{Introduction}

Currently one of the devastating problems faced by the world is global warming and pollution. These problems are the main cause of spreading of mosquito borne diseases. The mosquito is one of the most important groups of insects present all over the world except Antarctica (Fradin, 1998). Taxonomically the Culex quinquefasciatus belongs to family Culicidae, commonly called "southern house mosquito". They are dark yellow color and from small to moderate in size (Williams and Feltmate, 1992). The life cycle of mosquito is completed in four stages i.e. Eggs $\rightarrow$ Larva $\rightarrow$ $\mathrm{Pupa} \rightarrow$ Adult. The mosquito larva is also called "wriggler larva" that shows complete metamorphosis (Clements, 1992; Godfray, 1994). The females are sangivorous i.e. they suck blood of vertebrates' hosts. They are generally night biting mosquitoes (Williams and Feltmate, 1992).

A mature female mosquito mate only once in their entire life. After mating it feeds on blood of human and other eutherian mammals to complete the developmental stages of egg (Rozendaal, 1997). The adult female of $C x$. quinquefasciatus lays eggs in rafts forms during oviposition. It secretes pheromone and kairomones (special secreting substances like wax glands of honey bee) from their apical parts of the body (Laurence and Pickett, 1982). They lay eggs in organically enriched water and other food varieties with microbial decomposition (Poonam et al., 2002; Calhoun et al., 2007). Selection site for the oviposition depends upon the amount of nutrients in water (Chaves et al., 2009).

The $C x$. quinquefasciatus is most diverse group of mosquito species in Pakistan (Ilahi and Suleman, 2013), and act as a vector of many life threatening diseases, including, West Nile Virus and falariasis in particular. These diseases affect more than 120 million people worldwide annually. Mosquito also causing allergic reactions such as skin rashes and systemic reactions (WHO, 2010; Simonsen, 2009). Mosquito in genus Culex also cause pulmonary eosinophilia in peoples of native areas (Beg et al., 2001).

Various controlling strategies are available against different life cycle stages of mosquitoes. In particular botanical and synthetic (Commercial) pesticides known to act as larvicides, pupicide, and adulticides against vector mosquito (Shapiro and Micucci, 2003) are in used throughout the globe. The most common synthetic chemical insecticides formerly used for control of mosquitoes included organochlorine and organophosphate compounds (Ghosh et al., 2012). Other synthetic insecticides such as heptachlor, pyrethrum, lindane, dichloro-diphenyltrichloroethane (DDT), and diealderin are also proved to have showing effective mosquitocidal activity (Brown, 1986). Beside, causesing environmental pollution and killing non-targeted organisms (Lee et al., 2001), synthetic pesticides are non-biodegradable as well,and are hense lethal for long periode of time and lead to and causing many diseases in human and other animals (Sukumar et al., 1991).

In this regard, botanical pesticide are looking more fruitful.Many plants families, including, family Umbelliferae, Rosaceae, Simaroubaceae, Rutaceae, Compositae, Lauraceae, Labiatae, and Myrtaceae are known to produce insecticidal products.(González, 1984; Judd et al., 2002). Beside, producing insecticidal products, these plants are also beneficial to human and other animals as these act as a source of food and lead to play role in the maintenance of ecological balance and production of oxygen. Botanical pesticides are not lethal to non-target organism and are easily bio-degradable and environmental friendly as well (Corbino, 2000).

Ailanthus altissima (Haven tree) is reported beneficial for integrated pest management programs (Corbino, 2000). Artemisia scoparia (Jauky) is known to be used as a medicine for GIT infections, urinary tract infections, respiratory stimulant and anthelmintic (Akhtar et al., 2013). Justicia adhatoda has many economic and ethnobotanical importance and is known to exhibited good mosquitocidal activity against vectors mosquito, Cx. quinquefasciatus, Aedes, and Anopheles (Singh and Huidrom, 2013). Therefore, in the present study the toxicity of selected plants against different life cycle stages of vector mosquito, $C x$. quinquefasciatus was evaluated with the aims to discover suitable alternative pesticide that are target specific, environment friendly and more efficient in activity than synthetic pesticides.

\section{Materials and Methods}

In the present study, the leaves of Ailanthus altissima (local name Spena shandai), Artemisia scoparia (local name Jauky), and Justicia adhatoda (Linn) (local name Baikand) see were selected for larvicidal, pupicidal, and knock-down bioassay against Culex quinquefasciatus..

\subsection{Plant collection and extraction}

The matured fresh leaves and whole plant of Artemisia scoparia, Justicia adhatoda, and Ailanthus altissima see (Figure $1 \mathrm{a}, \mathrm{b}, \mathrm{c}$ ) were collected from Chakdara, Tehsil Adenzai Dir (Lower), Khyber Pakhtunkhwa, Pakistan. The plants were properly identified by an expert plant taxonomist. The selected plants were shade dried, and powdered by electrical grinding machine. The net weight approximately $500 \mathrm{gm}$ powder was obtained from each plant and then the powder was soaked in methanol solvent for one week after which they are filtered 
(a)

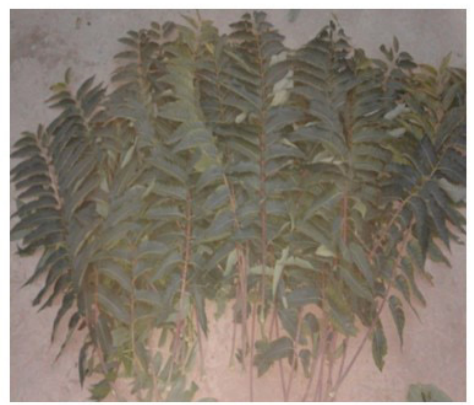

(b)

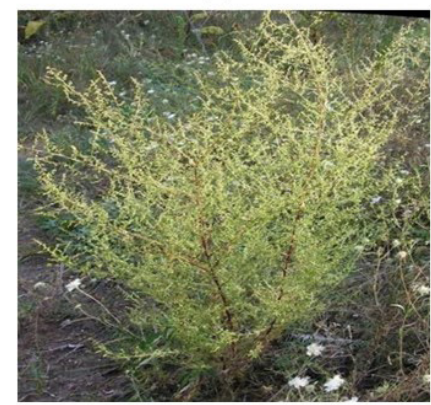

(c)

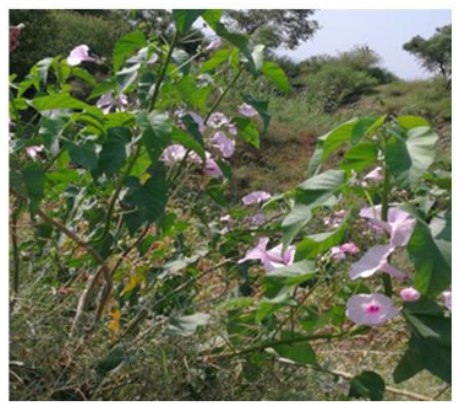

Figure 1. (a) Ailanthus altissima (Leaves) (b) Artemisia scoparia (c) Justicia adhatoda.

Table 1. Dry weight of the selected plants extracts and its fractions of various solvents.

\begin{tabular}{ccccccc}
\hline S.no & Plant Name & n-hexane & Ethyl Acetate & Chloroform & Methanol & Aqueous \\
\hline 1 & $\begin{array}{c}\text { Ailanthus } \\
\text { altissima }\end{array}$ & $12.40 \mathrm{~g}$ & $3.74 \mathrm{~g}$ & $0.00 \mathrm{~g}$ & $29.97 \mathrm{~g}$ & $52.50 \mathrm{~g}$ \\
2 & $\begin{array}{c}\text { Artemisia } \\
\text { scoparia } \\
\text { Justicia } \\
\text { adhatoda }\end{array}$ & $40 \mathrm{~g}$ & $0.50 \mathrm{~g}$ & $0.20 \mathrm{~g}$ & $18.76 \mathrm{~g}$ & $44 \mathrm{~g}$ \\
\hline
\end{tabular}

through Whatman Filter Paper No.42. The filtrate was then evaporated through rotary evaporator under reduce pressure. The methanolic extract thus obtained was then fractionated to n-hexane, ethyl acetate, chloroform and aqueous fraction using separating funnel. The yield of n-hexane, ethyl acetate, chloroform and aqueous fraction was approximately $1.4-1.8$ Liters. The yield was filtered through Whatman Filter Paper No.42 and then evaporated through rotary evaporator under reduce pressure. A thick solution of each filtrate was obtained that was transferred into a petri dish. The petri dishes were kept under running fan in shade. After drying, the net weight of n-hexane, ethyl acetate, chloroform and aqueous fraction obtained from methanolic extract of Ailanthus altissima was (Table 1) $12.40 \mathrm{~g}, 3.74 \mathrm{~g}, 0.00 \mathrm{~g}, 29.97 \mathrm{~g}$ and $52.50 \mathrm{~g}$ respectively while, it was $1.51 \mathrm{~g}, 2.90 \mathrm{~g}, 0.30 \mathrm{~g}$ and $25.65 \mathrm{~g}$ from 17.96g methanolic extract of Artemisia scoparia and $40 \mathrm{~g}, 0.50 \mathrm{~g}, 0.20 \mathrm{~g} 44 \mathrm{~g}$ from $18.76 \mathrm{~g}$ methanolic extract of Justicia adhatoda .

\subsection{Mosquito culture}

Before the mosquitocidal activity, the larvae of Culex quinquefasciatus of late $3^{\text {rd }}$ instar was collected from the channel of stagnant water near the campus of University of Malakand, Chakdara, Khyber Pakhtunkhwa, Pakistan, with the help of plastic jar and dipper. The immature larval stages were reared in a plastic jar till adult stage by adding a mixture of yeast and dog biscuits as larval food. The adult mosquitoes were captured with the help of aspirator. The taxonomic characters and identification of larvae and adult were confirmed under compound microscope using mosquito identification key (Barraud, 1934; Harbach and Kitching, 1998).

\subsection{Larvicidal and pupicidal bioassays}

For larvicidal and pupicidal activity, larvae were collected from entomology laboratory. A standard stock solution of 5000ppm of each plant extract and its fraction was prepared in distilled water. From the stock solution, tested concentrations (31.25ppm, 62.5ppm, 125ppm, $250 \mathrm{ppm}, 500 \mathrm{ppm}$ and $1000 \mathrm{ppm}$ ) of $100 \mathrm{ml}$ volume in tape water were prepared in plastic cups of $500 \mathrm{ml}$. To each plastic cup, twenty (20) larvae of $3^{\text {rd }}$ instar were added. All the activities were conceded at optimum temperature. After 24 hours of exposure period, the number of dead larvae and pupae were noted. Larvae and pupae were considered dead if they fail to move after rubbing through at siphon region. All these experiments were performed at optimum temperature and were repeated three times.

\subsection{Knock-Down bioassay}

Before the conduction of Knock-Down effect 5-6 days, mature glucose and blood fed adult female mosquitoes were used. The immature stages were reared in a plastic jar in laboratory inside a mosquito cage. The adult mosquitoes were captured through aspirator and subjected to Knock-Down effect following WHO standard procedure (WHO, 2010). The impregnated papers were placed in WHO test tubes. Each tube lid was put through a mosquito net. The knockdown (KD) effects of the extracts/fractions was observed every 15 minutes of 1 hour exposure period. Each experiment was repeated three times. $\mathrm{KDT}_{50}$ and $\mathrm{KDT}_{90}$ values were find out by probit analysis through SPSS No. 20.

\subsection{Statistical analysis of data}

The mortality were represented as mean \pm standard deviation of each three replicates. Abbott formula (Capinera, 
2004) was used where control mortality was greater than $5 \%$ and less than 20\%. For linear Regression and $\mathrm{R}$ square values of larval, pupal, and adult stage mortality Microsoft Excel 2010 was used. For the calculation of $\mathrm{LC}_{50}$ and $\mathrm{LC}_{90}$ and $\mathrm{KDT}_{50}$ and $\mathrm{KDT}_{90}$, and other statistic at 95\% confidence limit of upper confidence limit and lower confidence limit Probit Regression Analysis (Finney, 1971) using SPSS 20.0 version was used.

\section{Results}

Table 2 shows the activity of $n$-hexane, ethyl acetate and aqueous fraction obtained from methanolic extract of A. altissima, A. scoparia, and J. adhatoda against Culex quinquefasciatus larvae (late $3^{\text {rd }}$ or early $4^{\text {th }}$ instars). At The highest concentration of $1000 \mathrm{ppm}$ these fractions caused $98.7 \pm 1.5$ to $28.7 \pm 6 \%$ larval mortality while, at lowest concentration of $62.5 \mathrm{ppm}$ these fractions caused percent larval mortality of $3.3 \pm 3.1 \%$. The R square value was 0.97 to 0.75 . The ethyl acetate fraction from Justicia adhatoda was found the most active ( $\left.\mathrm{LC}_{50}: 93 \mathrm{ppm}\right)$, followed by the n-hexane fraction of Artemisia scoparia ( $\mathrm{LC}_{50}: 159.9 \mathrm{ppm}$ ) and ethyl acetate fraction of Ailanthus altissima ( $\mathrm{LC}_{50}$ : 274.1ppm).

\subsection{Pupicidal potential of various solvent fraction} of the selected plants Methanol extract against $C x$. quinquefasciatus

Table 3 shows the activity of $n$-hexane, ethyl acetate and aqueous fraction obtained from methanolic extract of A. altissima, A. scoparia, and J. adhatoda against pupae of Culex quinquefasciatu.. At the highest concentration of $1000 \mathrm{ppm}$ these fractions caused perecnt pupal mortality of $49.7 \pm 3.6$ to $13.3 \pm 1.2 \%$ while, at the lowest concentration of $62.5 \mathrm{ppm}$ these fractions caused perecnt pupal mortality of $6.7 \pm 2.1-4.7 \pm 1.5 \%$. The $R$ square value was $0.99-0.82$. The n-hexane fraction from Artemisia scoparia was found the most active $\left(\mathrm{LC}_{50}: 955.3 \mathrm{ppm}\right)$, followed by the ethyl acetate fraction of Justicia adhatoda ( $\left.\mathrm{LC}_{50}: 1326.7 \mathrm{ppm}\right)$.

\subsection{Knock-Down effect of Ethyl Acetate fractions of selected plants Methanol extract against Cx.quinquefasciatus}

Table 4 shows the susceptibility of adult $C x$. quinquefasciatus after 1 hour exposure period to various concentrations $(0.625$ to $01 \mathrm{mg} / \mathrm{ml})$ of A. altissima, A. scoparia and $J$. adhatoda ethyl acetate. The highest concentration $(1 \mathrm{mg} / \mathrm{ml})$ of this fraction caused $82 \pm 3.7-30.2 \pm 24.8 \%$ knockdown and lowest concentration $(0.625 \mathrm{mg} / \mathrm{ml})$ caused $24 \pm 9.1-17.15 \pm 5.3 \%$ knockdown of the tested mosquito. The $\mathrm{R}$ square value was $0.96-0.4$. The knockdown time fifty $\left(\mathrm{KDT}_{50}\right)$ values of this fraction were 0.30 - 2.8 and $\mathrm{KDT}_{90}$ values of this fraction fractions were 1.2 - 110.8, respectively.

\section{Discussion}

Mosquitoes are the deadly dangerous insect pests, which transmit many diseases of health importance in humans. Their control is therefor likely to be needed. Frequent use of pesticide of synthetic origin for the control of mosquito populations has disrupted naturally occurring biological control sachems and has initiated insecticide resistance in vector mosquitoes. Beside these synthetic pesticide used is also raised concern about the environment and human health. To control the populations of vectors mosquito currently, the emphasis is therefore shifted toward environment friendly and target specific materials.

Table 2. Larvicidal potential of differentfractions selected plants against Cx. quinquefasciatus after 24 hours exposure period.

\begin{tabular}{|c|c|c|c|c|c|c|c|c|c|c|}
\hline \multirow{2}{*}{$\begin{array}{c}\text { Plant } \\
\text { Species }\end{array}$} & \multirow{2}{*}{$\begin{array}{l}\text { Name of } \\
\text { Extract }\end{array}$} & \multicolumn{6}{|c|}{ Concentration (PPm) Mortality \% } & \multirow{2}{*}{$\begin{array}{c}\text { R- } \\
\text { square }\end{array}$} & \multirow{2}{*}{$\begin{array}{c}\text { LC }_{50} \\
(\mathrm{LCL}-\mathrm{UCL})\end{array}$} & \multirow{2}{*}{$\begin{array}{c}\text { LC }_{90} \\
(\mathrm{LCL}-\mathrm{UCL})\end{array}$} \\
\hline & & 1000 & 500 & 250 & 125 & 62.5 & 31.25 & & & \\
\hline \multirow[t]{3}{*}{$\begin{array}{l}\text { Ailanthus } \\
\text { altissima }\end{array}$} & n-hexane & $79.3 \pm 6.02$ & $47.7 \pm 6$ & $10.7 \pm 2.1$ & $9.5 \pm 1.52$ & $8.3 \pm 1.52$ & 0 & 0.96 & $\begin{array}{c}527.3 \\
(311-1430)\end{array}$ & $\begin{array}{c}2141.3 \\
(954-31680)\end{array}$ \\
\hline & $\begin{array}{c}\text { Ethyl } \\
\text { Acetate }\end{array}$ & $87.7 \pm 9.8$ & $70.3 \pm 11$ & $40.7 \pm 1.5$ & $28.3 \pm 3.1$ & $14.3 \pm 3.6$ & 0 & 0.94 & $\begin{array}{c}274.1 \\
(209-368)\end{array}$ & $\begin{array}{c}1191.9 \\
(778-2373)\end{array}$ \\
\hline & $\begin{array}{l}\text { Aqueous } \\
\text { Solution }\end{array}$ & $49.3 \pm 10$ & $32.7 \pm 4.8$ & $19.3 \pm 4.8$ & $8.7 \pm 3.2$ & $5.3 \pm 3.2$ & 0 & 0.97 & $\begin{array}{c}995.6 \\
(756-1426)\end{array}$ & $\begin{array}{l}7192.1 \\
(4129- \\
16421)\end{array}$ \\
\hline \multirow[t]{3}{*}{$\begin{array}{l}\text { Artemisia } \\
\text { scoparia }\end{array}$} & n-hexane & $98.3 \pm 2.1$ & $79.7 \pm 2.5$ & $59.7 \pm 2.1$ & $45.6 \pm 3.8$ & $27.7 \pm 3.2$ & $3.3 \pm 3.1$ & 0.75 & $\begin{array}{c}159.9 \\
(111-225.8)\end{array}$ & $\begin{array}{c}676.5 \\
(426-1550)\end{array}$ \\
\hline & $\begin{array}{c}\text { Ethyl } \\
\text { Acetate }\end{array}$ & $98.7 \pm 1.5$ & $88.3 \pm 6.6$ & $57.7 \pm 8.5$ & $39.7 \pm 5.5$ & $14.7 \pm 3.8$ & $3.3 \pm 3.1$ & 0.89 & $\begin{array}{c}172.6 \\
(153-195)\end{array}$ & $\begin{array}{c}474.4 \\
(706-950)\end{array}$ \\
\hline & $\begin{array}{l}\text { Aqueous } \\
\text { Solution }\end{array}$ & $28.7 \pm 6$ & $10.3 \pm 2.1$ & $5.7 \pm 1.5$ & 0 & 0 & 0 & 0.99 & $\begin{array}{c}1856.7 \\
(1339-3285)\end{array}$ & $\begin{array}{c}7635.5 \\
(4058-24597)\end{array}$ \\
\hline \multirow[t]{2}{*}{$\begin{array}{c}\text { Justicia } \\
\text { adhatoda }\end{array}$} & $\begin{array}{c}\text { Ethyl } \\
\text { Acetate }\end{array}$ & $98.7 \pm 1.5$ & $89.3 \pm 5.7$ & $79.3 \pm 4.04$ & $71.3 \pm 8.7$ & $31.2 \pm 1.5$ & $16.8 \pm 0.5$ & 0.89 & $\begin{array}{c}93 \\
(66-124)\end{array}$ & $\begin{array}{c}424 \\
(289.7-779)\end{array}$ \\
\hline & $\begin{array}{l}\text { Aqueous } \\
\text { Solution }\end{array}$ & $98.3 \pm 2.1$ & $79.3 \pm 2.1$ & $60.7 \pm 2.5$ & $38.7 \pm 1.5$ & $10.3 \pm 2.1$ & 0 & 0.95 & $\begin{array}{c}258.1 \\
(165-436)\end{array}$ & $\begin{array}{c}802.3 \\
(467-2941)\end{array}$ \\
\hline
\end{tabular}

$\mathrm{LC}_{50}$ : concentration causing $50 \%$ mortality; $\mathrm{LC}_{90}$ : concentration causing $90 \%$ mortality LCL: lower confidence limit; UCL: upper confidence limit 
Table 3. Pupicidal potential of different fractions from selected plants against Cx.quinquefasciatus after 24 hours exposure period.

\begin{tabular}{|c|c|c|c|c|c|c|c|c|c|}
\hline \multirow{2}{*}{$\begin{array}{c}\text { Plant } \\
\text { Species }\end{array}$} & \multirow{2}{*}{$\begin{array}{c}\text { Name of } \\
\text { Extract }\end{array}$} & \multicolumn{5}{|c|}{ Concentration (PPM) Mortality\% } & \multirow{2}{*}{$\begin{array}{c}\text { R- } \\
\text { Square }\end{array}$} & \multirow{2}{*}{$\begin{array}{c}\mathbf{L C}_{50} \\
(\mathrm{LCL}-\mathrm{UCL})\end{array}$} & \multirow{2}{*}{$\begin{array}{c}\text { LC }_{90} \\
(\text { LCL-UCL) }\end{array}$} \\
\hline & & 1000 & 500 & 250 & 125 & 62.5 & & & \\
\hline \multirow[t]{3}{*}{$\begin{array}{l}\text { Ailanthus } \\
\text { altissima }\end{array}$} & n-hexane & $29.3 \pm 1.5$ & $19.3 \pm 1.5$ & $13.7 \pm 4.04$ & $3.3 \pm 3.1$ & 0 & 0.95 & $\begin{array}{c}1742.5 \\
(928-14356)\end{array}$ & $\begin{array}{c}7192.7 \\
(3865-2774)\end{array}$ \\
\hline & $\begin{array}{c}\text { Ethyl } \\
\text { Acetate }\end{array}$ & $19.3 \pm 1.5$ & $13.7 \pm 4.04$ & $3.3 \pm 3.1$ & 0 & 0 & 0.97 & $\begin{array}{c}2163.3(1492- \\
4788)\end{array}$ & $\begin{array}{c}7502.6 \\
(3726-36289)\end{array}$ \\
\hline & $\begin{array}{l}\text { Aqueous } \\
\text { Solution }\end{array}$ & $13.3 \pm 1.2$ & $9.7 \pm 0.6$ & $6.7 \pm 1.5$ & $3.3 \pm 3.1$ & 0 & 0.94 & $\begin{array}{c}6818.4(3341- \\
75812)\end{array}$ & $\begin{array}{c}131031.4 \\
(2376-23706)\end{array}$ \\
\hline \multirow[t]{3}{*}{$\begin{array}{l}\text { Artemisia } \\
\text { scoparia }\end{array}$} & n-hexane & $49.7 \pm 3.6$ & $29.7 \pm 3.6$ & $9.3 \pm 2.1$ & $3.3 \pm 3.1$ & 0 & 0.99 & $\begin{array}{c}955.3 \\
(790-1232)\end{array}$ & $\begin{array}{c}3667.3 \\
(2499-6502)\end{array}$ \\
\hline & $\begin{array}{c}\text { Ethyl } \\
\text { Acetate }\end{array}$ & $39.7 \pm 1.5$ & $29.3 \pm 0.6$ & $19.7 \pm 3.06$ & $14.3 \pm 1.5$ & $4.7 \pm 1.5$ & 0.94 & $\begin{array}{c}1408.8 \\
(962-2615)\end{array}$ & $\begin{array}{c}16642 \\
(6942-76697)\end{array}$ \\
\hline & $\begin{array}{l}\text { Aqueous } \\
\text { Solution }\end{array}$ & $14.7 \pm 2.5$ & $5.7 \pm 2.1$ & $2.3 \pm 2.1$ & 0 & 0 & 0.99 & $\begin{array}{c}3572.2(1999- \\
14587)\end{array}$ & $\begin{array}{c}17427.9 \\
(6158-23743)\end{array}$ \\
\hline \multirow[t]{2}{*}{$\begin{array}{c}\text { Justicia } \\
\text { adhatoda }\end{array}$} & $\begin{array}{c}\text { Ethyl } \\
\text { Acetate }\end{array}$ & $42.3 \pm 3.0$ & $34.7 \pm 2.5$ & $25.3 \pm 1.5$ & $15.7 \pm 2.5$ & $6.7 \pm 2.1$ & 0.82 & $\begin{array}{c}1326.7 \\
(875-2673)\end{array}$ & $\begin{array}{c}23724 \\
(8488- \\
156044)\end{array}$ \\
\hline & $\begin{array}{l}\text { Aqueous } \\
\text { Solution }\end{array}$ & $38.7 \pm 3.6$ & $29.3 \pm 6.6$ & $18.7 \pm 3.5$ & $9.3 \pm .2 .1$ & $4.7 \pm 2.5$ & 0.90 & $\begin{array}{c}1436.8(1007- \\
2436)\end{array}$ & $\begin{array}{c}14279.7 \\
(6748-46911)\end{array}$ \\
\hline
\end{tabular}

$\mathrm{LC}_{50}$ concentration causing 50\% Mortality; $\mathrm{LC}_{90}$ : concentration causing 90\% Mortality; LCL: lower confidence limit; UCL: upper confidence limit.

Table 4. Knockdown (KDT) effects of Ethyl Acetate fractions of selected plants against $C x$. quinquefasciatus after 1 hour exposure period.

\begin{tabular}{|c|c|c|c|c|c|c|c|c|}
\hline \multirow{2}{*}{$\begin{array}{c}\text { Plant } \\
\text { Species }\end{array}$} & \multicolumn{5}{|c|}{ Concentration (mg/ml) Knock-Down (\%) } & \multirow{2}{*}{ R-Square } & \multirow{2}{*}{$\mathrm{KDT}_{50}(\mathrm{~L}-\mathrm{U})$} & \multirow{2}{*}{$\mathrm{KDT}_{90}(\mathrm{~L}-\mathrm{U})$} \\
\hline & 1 & 0.5 & 0.25 & 0.125 & 0.625 & & & \\
\hline $\begin{array}{l}\text { Ailanthus } \\
\text { altissima }\end{array}$ & $50.2 \pm 29.8$ & $32.7 \pm 9.2$ & $24.8 \pm 22.7$ & $17.15 \pm 5.3$ & 0 & 0.96 & $\begin{array}{c}1 \\
(0.5-13.3)\end{array}$ & $\begin{array}{c}7.5 \\
(1.2-160.8)\end{array}$ \\
\hline $\begin{array}{c}\text { Artemisia } \\
\text { scoparia }\end{array}$ & $30.2 \pm 24.8$ & $27.7 \pm 9.5$ & $25.4 \pm 13$ & $24 \pm 9.1$ & 0 & 0.4 & $\begin{array}{c}2.8 \\
(1.5-22.3)\end{array}$ & $\begin{array}{c}110.8 \\
(65.8-935.8)\end{array}$ \\
\hline $\begin{array}{c}\text { Justicia } \\
\text { adhatoda }\end{array}$ & $82 \pm 3.7$ & $69.2 \pm 3$ & $46.2 \pm 8.7$ & $30.2 \pm 10$ & 0 & 0.78 & $\begin{array}{c}0.30 \\
(0.16-0.60)\end{array}$ & $\begin{array}{c}1.2 \\
(0.61-11.8)\end{array}$ \\
\hline
\end{tabular}

KDT Knockdown time ; L lower unit ; U upper unit

Pesticide of botanical origin, which exhibit both lethal and sub-lethal effect against insect pests is looking more fruitful in this scenario. Botanical pesticides are biodegradable and because of the complex biomolecules synergistic action, the chances of resistance development in insect pests to botanical pesticides is also rare. As a result of these advantages currently the use of plants for developing botanical pesticides have globally got public attention including, the attention of scientific community in particular.

In search of botanical pesticide, in the present study, different extracts from Ailanthus altissima, Artemisia scoparia, and Justicia adhatoda were tested for their larvicidal, pupicidal, and adulticidal activity against vector mosquito, Culex quinquefasciatus. The ethyl acetate fraction from Justicia adhatoda with $\mathrm{LC}_{50}$ value of $93 \mathrm{ppm}$ against $3^{\text {rd }}$ instar larvae was found the most active larvicidal agent, followed by the $\mathrm{n}$-hexane fraction of Artemisia scoparia with $\mathrm{LC}_{50}$ value of $159.9 \mathrm{ppm}$ and ethyl acetate fraction of Ailanthus altissima with $\mathrm{LC}_{50}$ value of $274.1 \mathrm{ppm}$, respectively. Earlier studied have also revealed the extract of ethyl acetate from Letiota aspera with $\mathrm{LC}_{50}$ value of $138.6 \mathrm{ppm}$ against $3^{\text {rd }}$ instar larvae of Culex quinquefasciatus (Muthukrishnan et al., 1997), from Acalypha indica with $\mathrm{LC}_{50}$ value of $23.26 \mathrm{ppm}$ against the larvae of Anopheles stephensi (Govindarajan et al., 2008), from Acalypha indica with $\mathrm{LC}_{50}$ value of $140.69 \mathrm{ppm}$ against Cx. Quinquefasciatus (Sakthivadivel and Daniel, 2008), from Ocimum canum with $\mathrm{LC}_{50}$ value 95.74 and 101.3 ppm against $3^{\text {rd }}$ instar larvae of Anopheles stephensi and Culex quinquefasciatus (Kamaraj et al., 2008), from Cardiospermum halicacabum with $\mathrm{LC}_{50}$ value of $183.36 \mathrm{ppm}$ and 192.31 ppm against $C x$. quinquefasciatus and Aedes aegypti larvae (Govindarajan and Sivakumar, 2012), and from Adhatoda vasica with $\mathrm{LC}_{50}$ value of 156.04 against $3^{\text {rd }}$ instar larvae of $C x$. quinquefasciatus (Jayapriya and Shoba, 2015) to have exhibited the highest larvicidal activity. To act as larvicide botanical pesticides might have got the benefits of being safe to the environment and non-target organisms as well. .

In the pupicidal assay, the n-hexane fraction from Artemisia scoparia was observe to exert the highest pupicidal activity $\left(\mathrm{LC}_{50}: 955.3 \mathrm{ppm}\right)$, followed by the ethyl 
acetate fraction of Justicia adhatoda $\left(\mathrm{LC}_{50}: 1326.7 \mathrm{ppm}\right)$.The pupicida activity obtained in the present study was too lower than that reported by Ramar and Jeyasankar, (2016) for the leaves ethyl acetate extract of Pouzolzia bennettiana against Culex. Quinquefasciatus ( $\mathrm{LC}_{50}: 78.66 \mathrm{ppm}$ ), but was higher than that reported by Subarani et al.(2013) for the leaves ethyl acetate extract of Catharanthus roseus against Culex. Quinquefasciatus ( $\mathrm{LC}_{50}: 78.66 \mathrm{ppm}$ ), and Ashwini et al. (2017) for the leaves ethyl actate extract of Acalypha indica against Aedes aegypti ( $\left.\mathrm{LC}_{50}: 4472.14 \mathrm{ppm}\right)$.

In knockdown assay of the present study, the ethyl acetate fraction of Justicia adhatoda showed the highest knock-down effect $\left(\mathrm{KDT}_{50} 0.30 \%\right)$ followed by Ailanthus altissima ( $\mathrm{KDT}_{50} 1 \%$ ), and Artemisia scoparia (KDT ${ }_{50} 2.8 \%$ ) against adult female mosquitoes. The lowest $\mathrm{KDT}_{50}$ value obtained for Justicia adhatoda in the present study was significantly higher than that reported by Janakan and Ramakrishnan (2014) in their study for the leaf ethyl acetate extracts of Barleria prionitis $\left(\mathrm{KDT}_{50}: 484.56 \mathrm{ppm}\right)$ at the end of 24 hours exposure period against adult female mosquito of Culex quinquefasciatus.

Insecticide resistance and environmental pollution associated with synthetic pesticide used are likely challenges facing the control of vectors mosquito. In contrast, pesticides of botanical origin may serve suitable alternative techniques for the control of vectors mosquito. The usage of botanical pesticides for the control of mosquitoes has many positive characteristics as they are biodegradable, do not effect non-target organisms, ecofriendly, and a rich source of ingredients of valuable biological activities (Khanna et al., 2011). Moreover botanical pesticides are expected to be more effective than synthetic pesticides and therefore enhance the way to minimize dependence on synthetic pesticides (Wahyuni, 2015). The findings of the current study explored the effectiveness of ethyl acetate extract of Justicia adhatoda as a pesticide that should be further studied for identification of specific compounds.

\section{Conclusion}

The present study concluded that the Justicia adhatoda is most effective larvicidal, pupicidal, and adulticidal plant, followed by Artemisia scoparia, and Ailanthus altissima against $C x$. quinquefasciatus mosquito.

\section{Acknowledgements}

The Author AFZAL HUSSAIN acknowledged Associate Professor Dr. Ikram Ilahi Head of the Department of Zoology University of Malakand Chakdara Dir Lower Khyber Pakhtunkhwa, Pakistan who facilitate me in my research and provide me all the equipment's for my research also gratified to Dr. HUSSAIN Ahmed and Dr. Nawab Ali who give me a valuable time in my this journey.

\section{References}

AKHTAR, N., RASHID, A., MURAD, W., \& BERGMEIER, E., 2013. Diversity and use of ethno-medicinal plants in the region of
Swat, North Pakistan. Journal of Ethnobiology and Ethnomedicine, vol. 9, no. 1, pp. 25.

ASHWINI, U., TAJU, G., THIRUNAVUKKARASU, P. and ASHA, S., 2017. Pupal emergence inhibition activity of Acalypha Indica leaf extract against dengue vector, Aedes Albopictus mosquito. International Journal of Pharmacy and Pharmaceutical Sciences, vol. 9, no. 8, pp. 114-118. http://dx.doi.org/10.22159/ ijpps.2017v9i8.19362.

BARRAUD, C.P., 1934. The fauna of British India including Ceylon and Burma. London: Taylor and Francis, Red Lion Court.

BEG, M.A., NAQVI, A., ZAMAN, V. and HUSSAIN, R., 2001. Tropical Pulmonary Eosinophilia and Filariasis in Pakistan. South Eeast Asian Journal of Tropical Medicine., vol. 32, no. 1, pp. 73-75. PMid:11485099.

BROWN, A.W., 1986. Insecticide resistance in mosquitoes: a pragmatic review. Journal of the American Mosquito Control Association, vol. 2, no. 2, pp. 123-140. PMid:2906965.

CALHOUN, L. M., AVERY, M., JONES, L., GUNARTO, K., KING, R., ROBERTS, J., and BURKOT, T.R., 2007. Combined sewage overflows (CSO) are major urban breeding sites for Culex quinquefasciatus in Atlanta, Georgia. American Journal of Tropical Medicine Hygiene, vol. 77 , no. 3, pp. 478-484.

CAPINERA, J.L. (2004). Encyclopedia of Entomology. Dordrecht: Springer. Abbott's Formula.

CHAVES, L.F., KEOGH, C.L., VAZQUEZ-PROKOPEC, G.M. and KITRON, U.D., 2009. Combined sewage overflow enhances oviposition of Culex quinquefasciatus (Diptera: Culicidae) in urban areas. Journal of Medical Entomology, vol. 46, no. 2, pp. 220-226. http:// dx.doi.org/10.1603/033.046.0206. PMid:19351072.

CLEMENTS, A. R., 1992. The biology of mosquitoes. Development, nutrition, and reproduction. New York: Chapman and Hall, vol. 1.

CORBINO, G., 2000. Productos naturales vegetales de interés económico Instituto Nacional de Tecnología Agropecuaria. Buenos Aires, Argentina: Estación Experimental San Pedro.

FINNEY, D.J., 1971. Probit analysis. 3rd ed. Cambridge: Cambridge University Press, pp. 68-72.

FRADIN, M.S., 1998. Mosquitoes and mosquito repellents: a clinician's guide. Annals of Internal Medicine, vol. 128, no. 11, pp. 931-940. http://dx.doi.org/10.7326/0003-4819-128-11199806010-00013. PMid:9634433.

GHOSH, A., CHOWDHURY, N. and CHANDRA, G., 2012. Plant extracts as potential mosquito larvicides. The Indian Journal of Medical Research, vol. 135, no. 5, pp. 581-598. PMid:22771587.

GODFRAY, H.C.J., 1994. Parasitoids: behavioural and evolutionary ecology. Princeton, USA, Princeton University Press. http:// dx.doi.org/10.1515/9780691207025.

GONZÁLEZ, P., 1984. Utilización terapéutica de nuestras plantas medicinales. Bogotá: Universidad de La Salle, Cap. VI.

GOVINDARAJAN, M. and SIVAKUMAR, R., 2012. Repellent properties of Cardiospermum halicacabum Linn.(Family: Sapindaceae) plant leaf extracts against three important vector mosquitoes. Asian Pacific Journal of Tropical Biomedicine, vol. 2, no. 8, pp. 602-607. http://dx.doi.org/10.1016/S2221-1691(12)60105-1. PMid:23569979.

GOVINDARAJAN, M., JEBANESAN, A., PUSHPANATHAN, T. and SAMIDURAI, K., 2008. Studies on effect of Acalypha indica L. (Euphorbiaceae) leaf extracts on the malarial vector, Anopheles stephensi Liston (Diptera: culicidae). Parasitology Research, vol. 103, no. 3, pp. 691-695. http://dx.doi.org/10.1007/s00436-0081032-2. PMid: 18528709. 
HARBACH, R.E. and KITCHING, I.J., 1998. Phylogeny and classification of the Culicidae (Diptera). Systematic Entomology, vol. 23, no. 4, pp. 327-370. http://dx.doi.org/10.1046/j.1365-3113.1998.00072.x.

ILAHI, I. and SULEMAN, M., 2013. Species composition and relative abundance of mosquitoes in Swat, Pakistan. International Journal of Innovation and Applied Studies, vol. 2, no. 4. pp. 454-463.

JANAKAN, R. and RAMAKRISHNAN, N., 2014. Mosquito Larvicidal and adulticidal properties of botanical extract barleria prionits linn (Acanthaceae) Against Aedes aegypti Linn and Culex quinquefasciatus Say (Diptera: culicidae). International Journal of Current Innovation Research, vol. 1, no. 9, pp. 39-44.

JAYAPRIYA, G. and SHOBA, G., 2015. Larvicidal, ovicidal, adulticidal and repellent activity of Justicia Adhatoda Linn (Acanthaceae) against Aedes aegypti Linn and Culex quinquefasciatus say.JEZS, vol. 3, no. 1, pp. 154-159.

JUDD, W.S., CAMPELL, C.S., KELLOGG, E.A., STEVENS, P.F. and DONOGHUE, M.J., 2002. Secondary plants compounds. Plant systematic: a phylogenetic approach. In: STEVENS, P.F. Structural and biochemical characters. 2nd ed. USA: Sinaeur Associates, Chap 4.

KAMARAJ, C., RAHUMAN, A.A. and BAGAVAN, A., 2008. Screening for antifeedant and larvicidal activity of plant extracts against Helicoverpa armigera (Hübner), Sylepta derogata (F.) and Anopheles stephensi (Liston). Parasitology Research, vol. 103, no. 6, pp. 1361-1368. http://dx.doi.org/10.1007/s00436-0081142-x. PMid:18679716.

KHANNA, V.G., KANNABIRAN, K., RAJAKUMAR, G., RAHUMAN, A.A. and SANTHOSHKUMAR, T., 2011. Biolarvicidal compound gymnemagenol isolated from leaf extract of miracle fruit plant, Gymnema sylvestre (Retz) Schult against malaria and filariasis vectors. Parasitology Research, vol. 109, no. 5, pp. 1373-1386. http://dx.doi.org/10.1007/s00436-011-2384-6. PMid:21537987.

LAURENCE, B.R. and PICKETT, J.A., 1982. Erythro-6-acetoxy5-hexadecanolide, the major component of a mosquito oviposition attractant pheromone. Journal of the Chemical Society. Chemical Communications, vol. 1, no. 1, pp.59-60. http:// dx.doi.org/10.1039/c39820000059.

LEE, S.E., KIM, J.E. and LEE, H.S., 2001. Insecticide resistance in increasing interest. Journal of Applied Biological Chemistry, vol. 44, no. 3, pp. 105-112.

MUTHUKRISHNAN, J., PUSPHALATHA, E. and KASTHURIBHAI, A., 1997. Biological effects of four plant extracts on Culex quinquefasciatus Say larval stages. Insect Science and Its Application, vol. 17, no. 4, pp. 389-394.

POONAM, S., PAILY, K.P. and BALARAMAN, K., 2002. Oviposition attractancy of bacterial culture filtrates response of Culex quinquefasciatus. Memorias do Instituto Oswaldo Cruz, vol. 97, no. 3, pp. 359-362.

RAMAR, G. and JEYASANKAR, A., 2016. Mosquitocidal properties of Pouzolzia bennettiana var. acuta (Urticaceae) leaf extracts against three important human vector mosquitoes (Diptera: culicidae). International Journal of Entomology Research, vol. 1, no. 4, pp. 322-325.

ROZENDAAL, J.A., 1997. Vector control: methods for use by individuals and communities. Geneva: WHO.

SAKTHIVADIVEL, M. and DANIEL, T., 2008. Evaluation of certain insecticidal plants for the control of vector mosquitos' viz., Culex quinquefasciatus, Anopheles stephensi and Aedes aegypti. Applied Entomology and Zoology, vol. 43, no. 1, pp. 57-63. http:// dx.doi.org/10.1303/aez.2008.57.

SHAPIRO, H. and MICUCCI, S., 2003. Pesticide use for West Nile virus. Canadian Medical Association Journal, vol. 168, no. 11, pp. 1427-1430. PMid:12771072.

SIMONSEN, P.E. (2009). Filariases. In: G.C. COOK and A.I. ZUMLA, editors. Manson's tropical diseases. London: Saunders Elsevier, pp. 1477-1513 http://dx.doi.org/10.1016/B978-1-4160-44703.50088-4.

SINGH, K.J. and HUIDROM, D., 2013. Ethnobotanical uses of medicinal plant, Justicia adhatoda L. by Meitei community of Manipur, India. Journal of Coastal Life Medicine, vol. 1, no. 4, pp. 322-325.

SUBARANI, S., SABHANAYAKAM, S., KAMARAJ, C., ELANGO, G. and KADIR, M.A., 2013. Efficacy of larvicidal and pupicidal activity of Catharanthus roseus aqueous and solvent extracts against Anopheles stephensi Liston and Culex quinquefasciatus Say (Diptera: culicidae). Asian Pacific Journal of Tropical Medicine, vol. 6, no. 8, pp. 625-630. http://dx.doi.org/10.1016/S19957645(13)60107-8. PMid:23790333.

SUKUMAR, K., PERICH, M.J. and BOOBAR, L.R., 1991. Botanical derivatives in mosquito control: a review. Journal of the American Mosquito Control Association, vol. 7, no. 2, pp. 210237. PMid:1680152.

WAHYUNI, D., 2015. New bioinsecticide granules toxin from ectract of papaya (Carica papaya) seed and leaf modified against Aedes aegypti Larvae. Procedia Environmental Sciences, vol. 23, pp. 323-328. http://dx.doi.org/10.1016/j.proenv.2015.01.047.

WILLIAMS, D.D. and FELTMATE, B.W., 1992. Aquatic insects. Wallingford, Reino Unido: CAB international.

WORLD HEALTH ORGANIZATION - WHO, 2010 [viewed 22 January 2021]. Global program to estimate lymphatic filariasis [online]. Available from: http://www.who.int/lymphatic_filariasis/ disease/en/ 